\title{
Surveys of Afrotemperate forests yields two new freshwater crabs (Decapoda: Potamonautidae: Potamonautes MacLeay, 1838) from South Africa
}

\author{
Savel R. DANIELS ${ }^{1^{*}}$, Aaron BARNES $\circledast^{2}$, Hannes MARAIS ${ }^{3} \&$ Gavin GOUWS $\odot^{4}$ \\ ${ }^{1,2}$ Department of Botany and Zoology, Private Bag X1, University of Stellenbosch, Matieland, 7602, \\ South Africa. \\ ${ }^{3}$ Mpumalanga Tourism and Parks Agency, Aquatic Unit, Lydenburg, 1120, Mpumalanga, South Africa. \\ ${ }^{4}$ National Research Foundation - South African Institute for Aquatic Biodiversity, Private Bag 1015, \\ Makhanda, 6140, South Africa. \\ *Corresponding author: srd@sun.ac.za \\ ${ }^{2}$ Email: aaronbarnes88@gmail.com \\ ${ }^{3}$ Email: hanneswetlands@gmail.com \\ ${ }^{4}$ Email: gavingouws@gmail.com \\ *urn:1sid:zoobank.org:author:A036B72C-E34E-430F-8F58-7C24B01D0A77
${ }^{2}$ urn:1sid:zoobank.org:author:CBD65733-FD71-4AFE-A2C1-1C216C86F8D
${ }^{3}$ urn:1sid:zoobank.org:author:98A56701-E710-4A89-BCC2-00DC0BEDE75C
${ }^{4}$ urn:lsid:zoobank.org:author:E1B6ACB1-5777-4BB6-8204-60A7EA33B41D
}

\begin{abstract}
Sampling of remote inland aquatic habitats in South Africa has constantly been yielding novel endemic freshwater crab species (Potamonautes MacLeay,1838). During the present study, we report on the discovery and description of two new freshwater crab species (Potamonautes baziya sp. nov., and P. mariepskoppie sp. nov.) from Afrotemperate forested mountain regions in the Eastern Cape and Mpumalanga provinces of South Africa, respectively. Phylogenetic evidence derived from DNA sequence data of three partial mitochondrial loci (12S rRNA, 16S rRNA and cytochrome oxidase subunit one, COI) corroborates the evolutionary distinction of the two novel species. In addition, morphological and ecological data for the two new species further delineate their evolutionary distinction from congeneric sister species. A comparison of the taxonomically important gonopods 1 and 2 and carapace features among the sister species and other known freshwater crabs of South Africa was further used to provide evidence for the distinction of the two novel species. The discovery of two new species suggest that remote mountainous areas or unsampled regions in South Africa likely harbor several novel species, reiterating a call to document aquatic inland biodiversity in forested and mountainous regions of the country.
\end{abstract}

Keywords. Aquatic biodiversity, Decapoda, evolutionary relationships, novel lineages.

Daniels S.R., Barnes A. \& Marais H., Gouws G. 2021. Surveys of Afrotemperate forests yield two new freshwater crabs (Decapoda: Potamonautidae: Potamonautes MacLeay, 1838) from South Africa. European Journal of Taxonomy 782: 82-107. https://doi.org/10.5852/ejt.2021.782.1591 


\section{Introduction}

The alpha taxonomy of South African freshwater crabs (Potamonautes MacLeay, 1838) is well-established and an exemplar of one of the best studied inland aquatic crustacean groups in the Afrotropical region (Daniels 2017; Daniels et al. 2012, 2019; Peer et al. 2015, 2017; Phiri \& Daniels 2014, 2016). The discovery of new freshwater crab species was largely galvanized by the application of molecular tools such as allozyme electrophoresis and more recently DNA sequencing (Daniels 2017; Daniels et al. 2014, 2019, 2020b; Gouws et al. 2000, 2001; Peer et al. 2015, 2017; Phiri \& Daniels 2014, 2016). In addition, a new species is currently being described from Hogsback in the Eastern Cape Province (Peer pers. comm.). All of the recently documented diversity appears to be narrow endemic species, suggesting that fine-scale sampling is required to document the true taxonomic diversity of the group. Furthermore, the continued discovery of new freshwater crab species can be attributed to the fact that large areas of the country remain unsampled. These areas should be the focus of future systematic surveys, particularly in areas or biomes where habitats are naturally fragmented, creating an ideal template for allopatric speciation.

Currently, 24 Potamonautes species are known from South Africa, with inland aquatic habitats of the Eastern Cape and Mpumalanga provinces remaining particularly poorly sampled and likely harboring undescribed species. In the Eastern Cape, four freshwater crab species are present: P. barbarai Phiri \& Daniels, 2014, P. danielsi Peer \& Gouws, 2017, P. mhlophe Daniels, 2017, and the new, as yet undescribed freshwater crab species from Hogsback, along the Amathola Mountains (Peer pers. comm.). In Mpumalanga, five freshwater crab species are present: P. sidneyi Rathbun, 1904, P. warreni Calman, 1918, P. calcaratus Gordon, 1929, P. unispinus Stewart \& Cook, 1998 and P. flavusjo Daniels, Phiri \& Bayliss, 2014. Unpublished DNA sequence data indicate that $P$. danielsi is confined to southern KwaZuluNatal and the Eastern Cape provinces and does not occur in Mpumalanga province, as suggested by Peer et al. (2017) (Daniels unpubl.). Potamonautes sidneyi is a species complex that contains several cryptic lineages and is currently the focus of an ongoing study (Gouws et al. 2015; Daniels unpubl.). Recent surveys of inland freshwater systems in the Eastern Cape and Mpumalanga provinces resulted in the collection of morphologically distinct specimens that could not be assigned to any of the above or other described species. The specimens from Baziya forest station in the Eastern Cape were initially collected during a Foundational Biodiversity Initiative Program, funded by the National Research Foundation, that focused on forest biodiversity in the province. Initial genetic data from the Baziya freshwater crab specimens indicated that these were distinct from known species; however, the original specimens were subsequently lost, requiring resampling during the present study. While sampling wetlands, the second species was collected from the lowveld section of the Blyde Canyon Nature Reserve in the shadow of the Mariepskop Mountains in Mpumalanga Province. The purpose of the present study is to describe the two novel freshwater crab species, to determine their phylogenetic placement and compare their morphology with congeneric species present in South Africa.

\section{Material and methods}

Freshwater crabs were hand collected from under stones in streams in Afrotemperate forested areas at Baziya forest station in the Eastern Cape Province of South Africa. A total of 22 specimens were collected from Baziya. In addition, specimens were hand collected from forests at the Blyde Canyon Nature Reserve at Mariepskop in Mpumalanga Province. Only two adult males and four male juveniles were collected at Blyde Canyon Nature Reserve; no females were found. In addition, Dr N. Peer provided a tissue sample of the new, as yet undescribed species from Hogsback, allowing us to determine the phylogenetic position of the species. A handheld GPS was used to record latitude and longitude, and freshwater crabs were preserved in absolute ethanol. Both new species were photographed in the laboratory, while images of the live Baziya specimens were also captured in the field with a Canon EOS 
90D camera with a Sigma $105 \mathrm{~mm}$ f2.8 Macro USM lens. The image of the live Blyde Canyon Nature Reserve species was captured with the use of a Huawei P20 Lite cellular phone.

\section{DNA extraction, PCR and sequencing}

Muscle tissue, extracted from walking legs, was subjected to DNA extraction using a Nucleospin kit (Macherey-Nagel, Duren, Germany), following the manufacturers protocol. Extracted DNA was stored in a refrigerator at $-20^{\circ} \mathrm{C}$ until required for PCR. Generally, a $1 \mu 1$ DNA in $19 \mu 1$ water dilution was performed prior to use. Three partial mtDNA gene fragments were selected for the present study; these included cytochrome oxidase subunit one (COI), 12S rRNA and 16S rRNA. These three loci were selected because each has a different mutational rate and have been successfully used for reconstructing evolutionary relationships among freshwater crabs (Daniels et al.2002a, 2002b, 2006, 2015, 2019, 2020a, 2020b; Phiri \& Daniels 2014, 2016; Gouws et al. 2015; Wood \& Daniels 2016; Daniels \& Klaus 2018). Primer pairs are outlined in Daniels et al. $(2002 b, 2006,2015)$. Standard PCR conditions for amplification and DNA sequencing protocols were followed (Daniels et al. 2006, 2015, 2019, 2020a, 2020b; Daniels 2017). Sequences of each of the three mitochondrial gene regions were downloaded from GenBank for all the described southern African freshwater crab species (Daniels et al. 2002b, 2014, 2019; Daniels \& Bayliss 2012; Phiri \& Daniels 2014; Peer et al. 2015, 2017; Wood \& Daniels 2016; Daniels 2017) and included to understand the phylogenetic placement of the two new species from the present study and the undescribed species from Hogsback. Four species of Liberonautes Bott, 1955 (L. latidactylus (De Man, 1903), L. rubigimanus Cumberlidge \& Sachs, 1989, L. lugbe Cumberlidge, 1999 and L. nimba Cumberlidge, 1999) were used as outgroups, since this genus is sister to Potamonautes (Daniels et al. 2015).

\section{Phylogenetic analyses}

Sequence Navigator (Applied Biosystems) was used to compute a consensus sequence from forward and reverse strands for each of the three gene fragments. No insertions or deletions were evident for the protein-coding COI locus and sequences for this locus were aligned manually. The $12 \mathrm{~S}$ rRNA and $16 \mathrm{~S}$ rRNA loci were aligned using Clustal X ver. 2.1 (Thompson et al. 1997). Since all three fragments occur on the mitochondria and are linked, we combined the DNA sequence data for the three fragments into a single data matrix and conducted all analyses on the combined data set. Maximum Likelihood (ML) and Bayesian approaches were used to estimate evolutionary relationships. jModelTest (Posada 2008) was used to obtain the best-fit substitution model for each of the three gene loci (results not shown). These substitution models were used in a partitioned Bayesian analyses. The best-fit substitution models were chosen using the Akaike Information Criteria (AIC) (Akaike 1973). Maximum likelihood tree inference was conducted on the concatenated data set using the IQ-Tree web server (ver. 1.4.3, http://iqtree.cibiv. univie.ac.at/, Trifinopoulos et al. 2016). A single replicate search was conducted for the best tree. Branch support values were estimated using an ultrafast bootstrap analysis with 10000 pseudoreplicates and parameters set to default. Bootstrap values $>75 \%$ were deemed as sufficient support for nodes. Analyses were performed using a heuristic search algorithm starting at a random tree. Four rate categories were included for gamma and base frequencies were estimated. Bootstrap values were discerned during the online analysis and incorporated into the consensus tree generated. Bayesian inferences was used to investigate optimal tree space using the program MRBAYES ver. 3.2.6 (Ronquist et al. 2012). Four Markov chains were run, with each chain starting from a random tree and run for fifty million generations, sampling each chain every $10000^{\text {th }}$ tree. This process was repeated four times to ensure that trees converged on the same topology using MRBAYES. A 50\% majority rule consensus tree was generated from the trees retained (after the trees from the burn-in determined using likelihood plots were discarded) with posterior probabilities ( $\mathrm{pP}$ ) for each node estimated by the percentage of time the node was recovered. Posterior probability values $<0.95 \mathrm{pP}$ were regarded as poorly resolved (Daniels et al. 
2019). Uncorrected 'p' distances among sister species were calculated for the COI locus in PAUP ver. $4.0 \mathrm{~b} 10$ (Swofford 2002).

\section{Morphology}

Characters for male and female specimens from Baziya were considered separately, since freshwater crabs exhibit sexual dimorphism. As no females were sampled at the Blyde Canyon Nature Reserve, no differences between the sexes were quantified. The following measurements were taken with digital callipers: carapace length (CL); the carapace width at widest point (CWW); the width of the posterior margin of the carapace (CWP); the distance between the postfrontal crest and the anterior margin of the carapace (PFCD); the frontal width, measured between the medial margins of the orbits (FW); the distance between the exorbital teeth (CWA); the carapace height $(\mathrm{CH})$; the length and width of the merus of pereiopods 2 and 5 (PML and PMW); the length of the propodus of the major cheliped (MCPL); as well as the major cheliped dactylus length (MCDL). All measurements are given in millimetres (mm). Samples have been deposited in the South African Museum of Natural History, Iziko Museums of Cape Town (SAM A). The structure of gonopods 1 and 2 of the two new species are compared to that of other congeneric species. In addition, the major and minor cheliped of the new species were photographed with a $31 \mathrm{~mm}$ extension tube to the aforementioned setup to increase magnification.

\section{Results}

New sequences were deposited in GenBank (COI accession numbers OK489797-OK489798, 12S rRNA accession numbers OK482906-OK482907 and 16SrRNA accession numbers OK482901-OK482902). The ML and BI tree topologies were nearly identical; hence only the ML tree topology is shown. The ML and BI phylogenetic analyses based on the 1278 nucleotides of the three combined mtDNA loci, comprising $600 \mathrm{bp}, 316 \mathrm{bp}$ and $362 \mathrm{bp}$ fragments for COI, 12S rRNA and 16S rRNA, respectively, retrieved a monophyletic and statistically well-supported Potamonautes MacLeay, 1838 (Fig. 1). Since the tree topologies for the ML and BI analyses were nearly identical, we show only the ML tree topology, comprising three distinct clades. Clade $1(>75 \% />0.95 \mathrm{pP})$ contained five East African freshwater crab species, with $P$. namuliensis Daniels \& Bayliss, 2012 being basal to a clade containing $P$. choloensis Chace, 1953 sister to P. licoensis Daniels, Bittencourt-Silva, Muianga \& Bayliss, 2020 while the latter clade was sister to P. calcaratus Gordon, 1929 and P. obesus A. Milne-Edwards, 1868. Potamonautes bellarussus Daniels, Phiri \& Bayliss, 2014 was equidistant between clades 1 and 2. Clade 2 also comprised species from East Africa, with P. niloticus H. Milne-Edwards, 1837 being basal to a clade comprised of $P$. odheri Colosi, 1924 sister to P. subukia Cumberlidge \& Dobson, 2008, while the latter clade was in turn sister to P. raybouldi Cumberlidge \& Vannini, 2004 sister to P. platynotes Cunnington, 1907, and the latter two species sister to P. supracilcatus Hilgendorf, 1898 and P. lirrangensis Rathbun, 1904. Clade $3(>75 \%$ / >0.95pP) contained southern African freshwater crab species exclusively. The southern African mountain stream species comprised one clade, with P. baziya sp. nov., from the Baziya forest station in the Eastern Cape as sister to two Drakensberg Mountain endemic species, P. clarus Gouws, Stewart \& Coke, 2000 and $P$. depressus Krauss,1843. The latter clade was in turn sister to species from the Cape Folds Mountain (CFM), with P. sp. nov. from Hogback as sister to P. parvispina Stewart, 1997, and this clade was sister to P. parvicorpus Daniels, Stewart \& Burmeister, 2001 sister to $P$. brincki Bott, 1960 sister to P. tuerkayi Wood \& Daniels, 2016. The three forest-living species was basal to a large-bodied riverine dwelling clade and comprised $P$. danielsi sister to $P$. lividus Gouws, Stewart \& Reavell, 2001 and $P$. isimangaliso Peer \& Gouws, 2015. This large-bodied riverine clade comprised P. bayonianus Brito-Capello, 1864 sister to P. unispinus Stewart \& Cook, 1998 and P. warreni Calman, 1918, and these species were in turn sister to P. sidneyi Rathbun, 1904 sister to P. perlatus H. Milne Edwards, 1837, P. granularis Daniels, Stewart \& Gibbons, 1998, P. barnardi Phiri \& Daniels, 2014 and P. barbarai Phiri \& Daniels, 2014. The final clade comprised mainly temperate/ tropical freshwater crab species with P. mhlophe Daniels, 2017 sister to P. dentatus Stewart, Cook \& Coke, 1995, and this clade 
was sister to a larger clade containing $P$. gorongosa Cumberlidge, Naskrecki \& Daniels, 2017 sister to P. mutareensis Phiri \& Daniels, 2013; while P. flavusjo Daniels, Phiri \& Bayliss, 2014 was sister to a clade containing P. mulanjeensis Daniels \& Bayliss, 2012 sister species to P. ntendekaensis Daniels, Busschau \& Cumberlidge, 2019 and P. mariepskoppie sp. nov., sister to P. ngoyensis Daniels, Busschau \& Cumberlidge, 2019.

The average uncorrected COI sequence 'p' distance between $P$. baziya sp. nov. and its two sister species was $13.03 \%$. The uncorrected COI 'p' distance between P. mariepskoppie sp. nov. and P. ngoyensis was $8.65 \%$, while the 'p' distance between $P$. mariepskoppie sp. nov. and $P$. ntendekaensis was $10.90 \%$. The ' $\mathrm{p}$ ' distance between $P$. ngoyensis and P. ntendekaensis was $8.10 \%$. The uncorrected distance between $P$. licoensis and $P$. choloensis was $8.67 \%$. Among the small-bodied, mountain-living freshwater crab species endemic to the Cape Fold Mountains, the COI 'p' distance between P. parvispina and $P$. parvicorpus was $7.36 \%$ and $8.56 \%$ between $P$. brincki and $P$. tuerkayi. Finally, the uncorrected distance between P. parvispina and its sister, the new as yet undescribed species from Hogsback, was 7.81\%. The uncorrected COI sequence distance we observed between the two putative novel lineages in the present study, $>7.30 \%$, is comparable to what has been observed in previous studies. The phylogenetic results, together with the marked COI ' $p$ ' distance values, and the morphological differences, support the recognition of two novel freshwater crab species, the description of which follows.

Infraorder Brachyura Latreille, 1802

Superfamily Potamoidea Ortmann, 1896

Family Potamonautidae Bott, 1970

Subfamily Potamonautinae Bott, 1970

Genus Potamonautes MacLeay, 1838

Potamonautes mariepskoppie sp. nov. urn:1sid:zoobank.org:act:C0AE6C3E-5460-450C-87D4-87D24DC47862

Figs $1-6$

\section{Diagnosis}

Measurements for the holotype as follows: $\mathrm{CL}=19.07 \mathrm{~mm}$; $\mathrm{CWW}=26.76 \mathrm{~mm}$; $\mathrm{CWP}=11.56 \mathrm{~mm}$; $\mathrm{FW}=11.58 \mathrm{~mm} ; \mathrm{PFCD}=2.89 \mathrm{~mm} ; \mathrm{CH}=10.63 \mathrm{~mm} ; \mathrm{MCPL}=16.44 \mathrm{~mm} ; \mathrm{MCDL}=10.14 \mathrm{~mm}$; $\mathrm{P} 2 \mathrm{ML}=11.06 \mathrm{~mm} ; \mathrm{P} 2 \mathrm{MW}=4.65 \mathrm{~mm} ; \mathrm{P} 5 \mathrm{ML}=9.34 \mathrm{~mm} ; \mathrm{P} 5 \mathrm{MW}=3.61 \mathrm{~mm}$.

CARAPACE. Highly arched $(\mathrm{CH} / \mathrm{CL}=0.55)$ postfrontal crest well-defined, complete, lateral ends meeting anterolateral margins; epigastric crests faint, median sulcus between crests short, not forked posteriorly; exorbital, epibranchial teeth reduced to granules; anterolateral carapace margin with no tooth on epibranchial (Fig. 2A-C).

THIRD MAXILLIPED. Ischium with distinct vertical sulcus; $\mathrm{s} 3 / \mathrm{s} 4$ complete, $\mathrm{V}$-shaped, deep, midpoint almost meeting anterior margin of sterno-pleonal cavity; margins of s4 low, not raised (Fig. 2B).

CHELIPED. Dactylus (moveable finger) slim, highly arched, enclosing oval interspace, with three larger teeth interspersed by smaller teeth along length; propodus (fixed finger) with four larger teeth interspersed by smaller teeth along length (Fig. 2C); carpus inner margin distal tooth large, pointed, proximal tooth reduced to granules; medial inferior margin of merus lined with series of small granules terminating distally at small, low distal meral tooth, lateral inferior margin smooth.

G1 TERMINAL ARTICLE. $1 / 3$ rd length of subterminal; first third straight in line with longitudinal axis of subterminal, middle part directed outward at $45^{\circ}$, widened by raised rounded ventral lobe, tip curving sharply upward (Fig. 3A-B). 


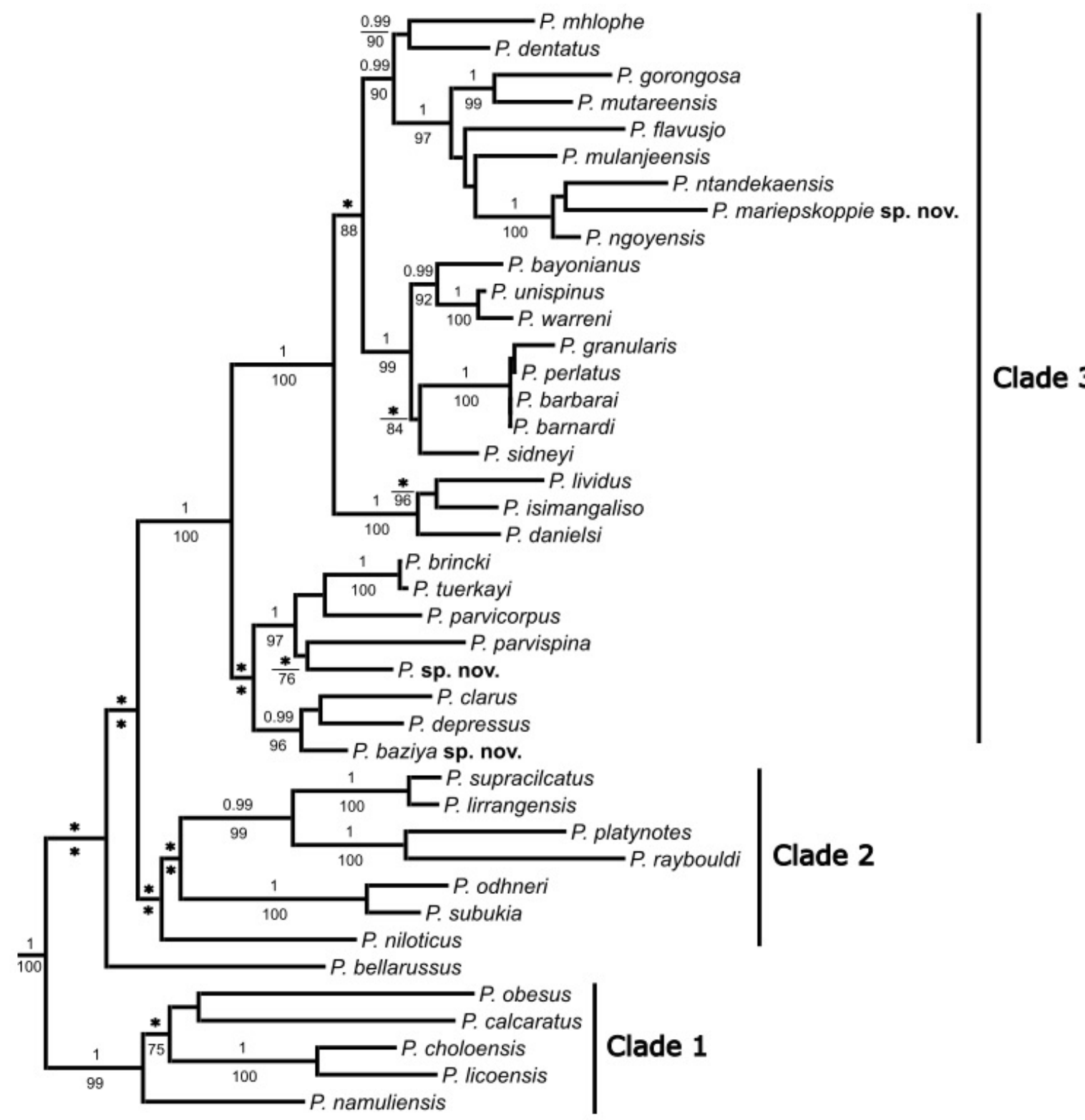

Fig. 1. A Maximum Likelihood tree topology derived for the three mtDNA loci (12S rRNA +16S rRNA + COI) for the eastern and southern African freshwater crab genus Potamonautes, with the outgroups removed. Bootstrap values $>75 \%$ are indicated below each node while posterior probability values $>0.95 \mathrm{p} P$ are shown above each node. An asterisk $(*)$ above or below a node indicates the lack of statistical support. The new, as yet undescribed species from Hogsback is demarked as $P$. sp. nov. on the phylogenetic tree. Clades 1 and 2 refers to predominantly East African species, while clade 3 refers to the southern African clade. 


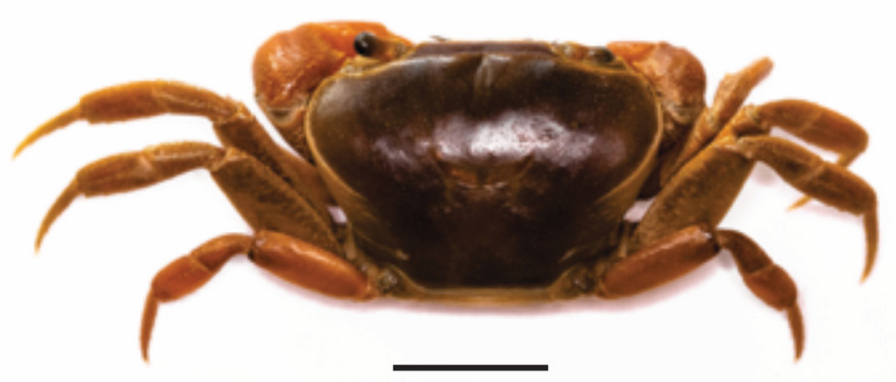

A

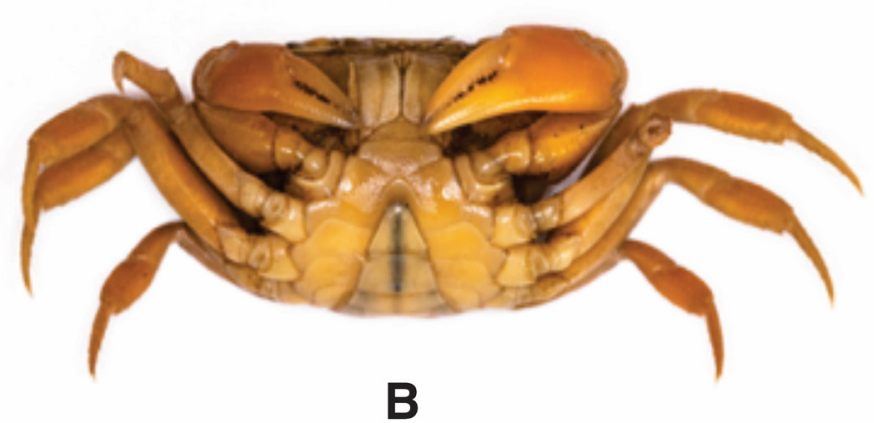

B

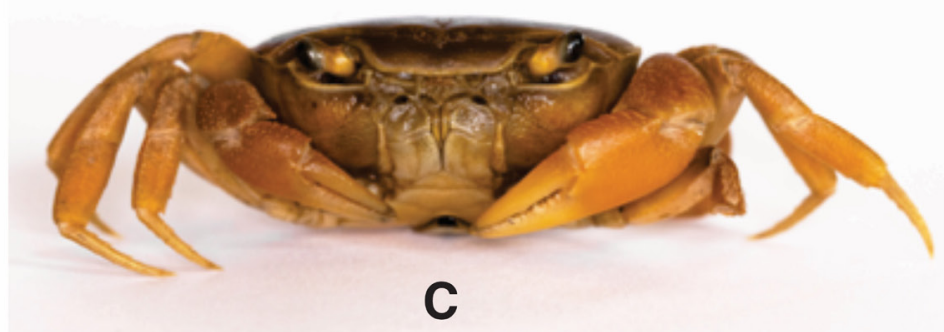

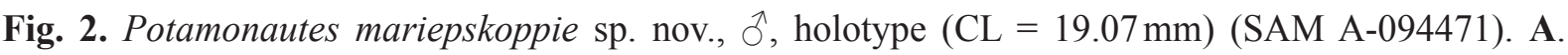
Entire animal, dorsal aspect. B. Entire animal, ventral aspect. C. Cephalothorax, frontal aspect. Scale bar $=10 \mathrm{~mm}$. 


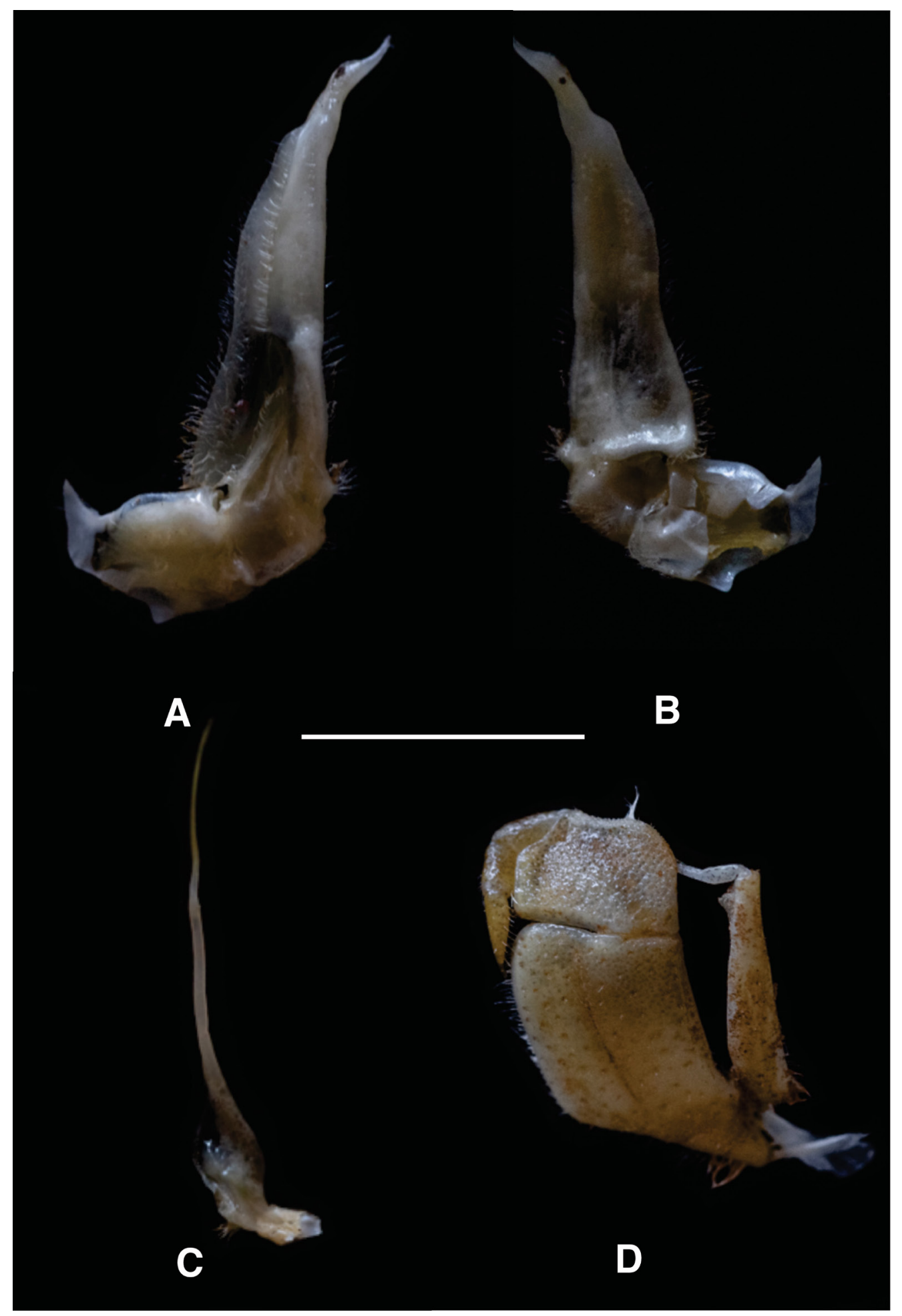

Fig. 3. Potamonautes mariepskoppie sp. nov., $\widehat{\jmath}$, holotype (SAM A-094471) A. Left gonopod 1, anterior view. B. Left gonopod 1, posterior view. C. Left gonopod 2, anterior view. D. Right third maxilliped. Scale bar $=10 \mathrm{~mm}$. 


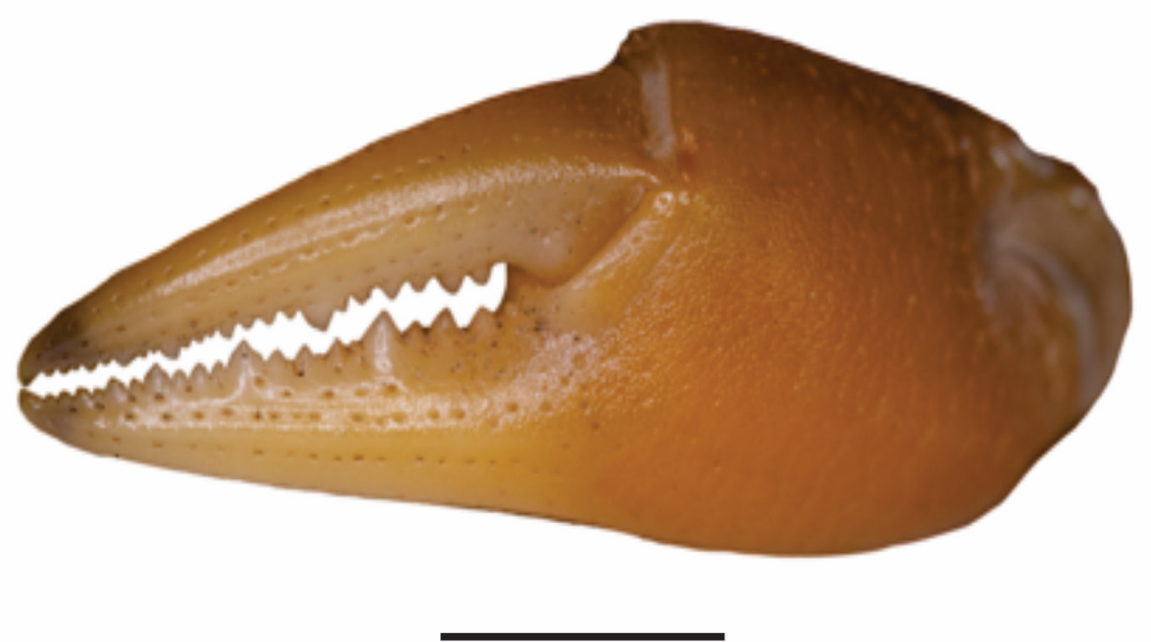

A

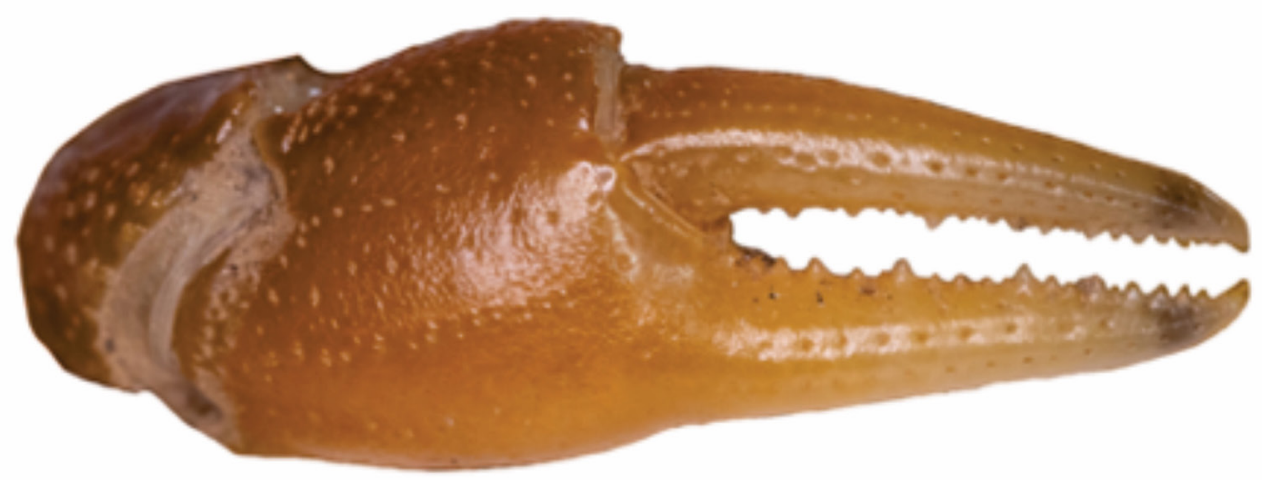

B

Fig. 4. Potamonautes mariepskoppie sp. nov., $\widehat{\partial}$, holotype (SAM A-094471) A. Major right cheliped. B. Minor left cheliped. Scale bar $=10 \mathrm{~mm}$. 


\section{Etymology}

Named after Mariepskop since it occurs in close proximity to the mountain. The specific epithet is used as a Latin noun in apposition.

\section{Material examined}

\section{Holotype}

SOUTH AFRICA - Mpumalanga Province - 3 ; Blyde Canyon Nature Reserve, lowveld section, forest wetland; 2442'36.36" S, 3054'11.664" E; 733 m a.s.1.; 21 May 2021; H. Marais leg.; SAM A-094471.

\section{Paratype}

SOUTH AFRICA - Mpumalanga Province 1 ô; same collection data as for holotype except 17 Jun. 2020; SAM A-094472.

\section{Other material}

SOUTH AFRICA - Mpumalanga Province - 4 juvs; same collection data as for paratype; SAM A-094473.

\section{Description}

Based on the adult male holotype (CWW $26.76 \mathrm{~mm}$ ).

CARAPACE. Smooth with no tooth on the anteriolateral margins; widest anteriorly, narrowest posteriorly (CWP/CL 0.60); vaulted (CH/CL 0.55) (Fig. 2A); front broad, one-third of CWW (FW/CWW 0.43); urogastric, cardiac grooves distinct, other grooves faint or missing; postfrontal crest complete, anterolateral margin posterior to epibranchial corner finely granulated, epigastric crests faint, median sulcus between crests short, forked posteriorly; exorbital, epibranchial teeth each reduced to granules; anterolateral margin between exorbital, epibranchial teeth faintly granulated, curving slightly outward, lacking intermediate tooth (Fig. 2B-C); branchiostegal wall vertical sulcus faint, meeting longitudinal sulcus, dividing branchiostegal wall into 3 parts, suborbital, dorsal pterygostomial regions granulated, hepatic region smooth; suborbital margin faintly granulated.

THIRD MAXILLIPED. Filling entire buccal frame, except for respiratory openings; exopod with long flagellum, ischium with faint vertical groove (Fig. 3D). Epistomial tooth large, triangular, margins lined by large granules.

MandiBle. Palp two-segmented; terminal simple; tuft of setae at junction between segments.

Sternum. s1, s2 fused; s2/s3 deep, completely crossing sternum; s3/s4 complete, V-shaped, deep, midpoint almost meeting anterior margin of sterno-pleonal cavity; margins of s4 low, not raised.

Cheliped. Dactylus (moveable finger) slim, arched, with two teeth interspersed by smaller teeth along length; propodus (fixed finger) with two teeth interspersed by several smaller teeth along length (Fig. 4A-B), tips of both propodus and dactylus black; carpus distal tooth large, pointed, proximal tooth small but distinct, followed by granule; both inferior margins of merus lined with series of small granules, distal meral tooth small, pointed.

Pereopods. Walking legs slender, 3 longest, 5 shortest; dorsal margins of pereopods with fine sharp bristles, dactyli of walking legs ending in sharp point, with rows of spine-like bristles.

Pleon. Outline broadly triangular with straight margins. 
G1 TERMinAL ARTICLE. Short ( $1 / 3$ length of subterminal), curving away from midline, first third straight in line with longitudinal axis of subterminal segment, middle part directed outward at $45^{\circ}$, widened by low raised rounded ventral lobe, tip curving gently upward. G1 subterminal broad at base, tapering to slim junction with terminal article distally where these two parts have same width, ventral side with heavily setose margins; with setae-fringed flap covering lateral half of segment; dorsal side smooth, no flap, with broad membrane on dorsal side of suture marking junction between terminal, subterminal parts (Fig. $3 \mathrm{~A}-\mathrm{B})$.

G2 terminal ARTiCle. Long, flagellum-like, 0.5 times length of subterminal (Fig. 3C).

\section{Size}

A small-bodied species, $\mathrm{CL}=19.07 \mathrm{~mm}$, and wide, $\mathrm{CWW}=26.76 \mathrm{~mm}$.

\section{Colour in life}

Dorsal carapace chocolate brown with a glossy shine, while the chelipeds and ventral surface are light orange in colour (Fig. 5A).

\section{Distribution}

Known only from the lowveld section of the Blyde Canyon Nature Reserve, east of Mariepskop, Mpumalanga Province, South Africa. However, a digital photographic record from iNaturalist (posted by Werner Conradie) suggests the species is also present around Haenertsburg, in Limpopo Province, South Africa (Fig. 5B). Surveys of the latter area are required to confirm this observation.

\section{Ecology}

The type locality is located $12 \mathrm{~km}$ southeast of Mariepskop Mountain and forms part of the Great Drakensberg Mountain escarpment. The swamp forest receives annual rainfall averaging $1500 \mathrm{~mm}$ on top of the mountain and $750 \mathrm{~mm}$ at the bottom (Ngwenya et al. 2019). The swamp forests in these areas are all channelled valley-bottom wetlands with connected seeps. The wetland of the type locality is on a shallow gradient that allows the water to seep out slowly into shallow channels and forms shallow muddy puddles, which the crab species prefers. Potamonautes mariepskoppie sp. nov., occurs sympatrically with $P$. sidneyi sensu stricto. The soils are predominantly organic soils of $15-100 \mathrm{~cm}$ deep (Van Rooyen et al. 2020). The presence of large water berries, Syzygium cordatum, is diagnostic of these swamp forests. There are other wetland species present, such as Carex spicata-paniculata, Commelina benghalensis, Cyperus denudatus, Cyclosorus interruptus, Cyperus dives, Isolepis fluitans, Kyllinga odorata, Leersia hexandra, Persicaria decipiens, Selaginella kraussiana, Schoenoplectus brachyceras, Setaria megaphylla, Scleria transvaalensis and Thelypteris confluens.

\section{Remarks}

Potamonautes mariepskoppie sp. nov., can be distinguished from its two sister species, $P$. ngoyensis and $P$. ntendekaensis, using colour when alive. Potamonautes mariepskoppie sp. nov. has a chocolate brown carapace and orange chelipeds that vary to rust brown as does the specimen from Haenertsburg, Limpopo (Fig. 5B). Potamonautes ngoyensis has a pale-white carapace and chelipeds; P. Potamonautes ntendekaensis has a chocolate-coloured carapace with red pereopods; the entire animal fades to bright orange/red when preserved in absolute ethanol (Daniels et al. 2019). In addition, P. mariepskoppie sp. nov. is a small-bodied species $(\mathrm{CWW}=26.76 \mathrm{~mm})$ with a highly arched carapace $(\mathrm{CH} / \mathrm{CL}=0.60)$, while $P$. ngoyensis is a large-bodied $(\mathrm{CWW}=32.8 \mathrm{~mm})$ and flat species $(\mathrm{CH} / \mathrm{CL}=0.50)$. Similarly, P. ntendekaensis is a large-bodied species $(\mathrm{CWW}=37.56 \mathrm{~mm})$, that is highly arched $(\mathrm{CH} / \mathrm{CL}=$ 0.55). All three species appear to be narrow-endemic forest-dwelling species and are poorly collected based on current distribution records. Potamonautes mariepskoppie sp. nov. appears to be confined 


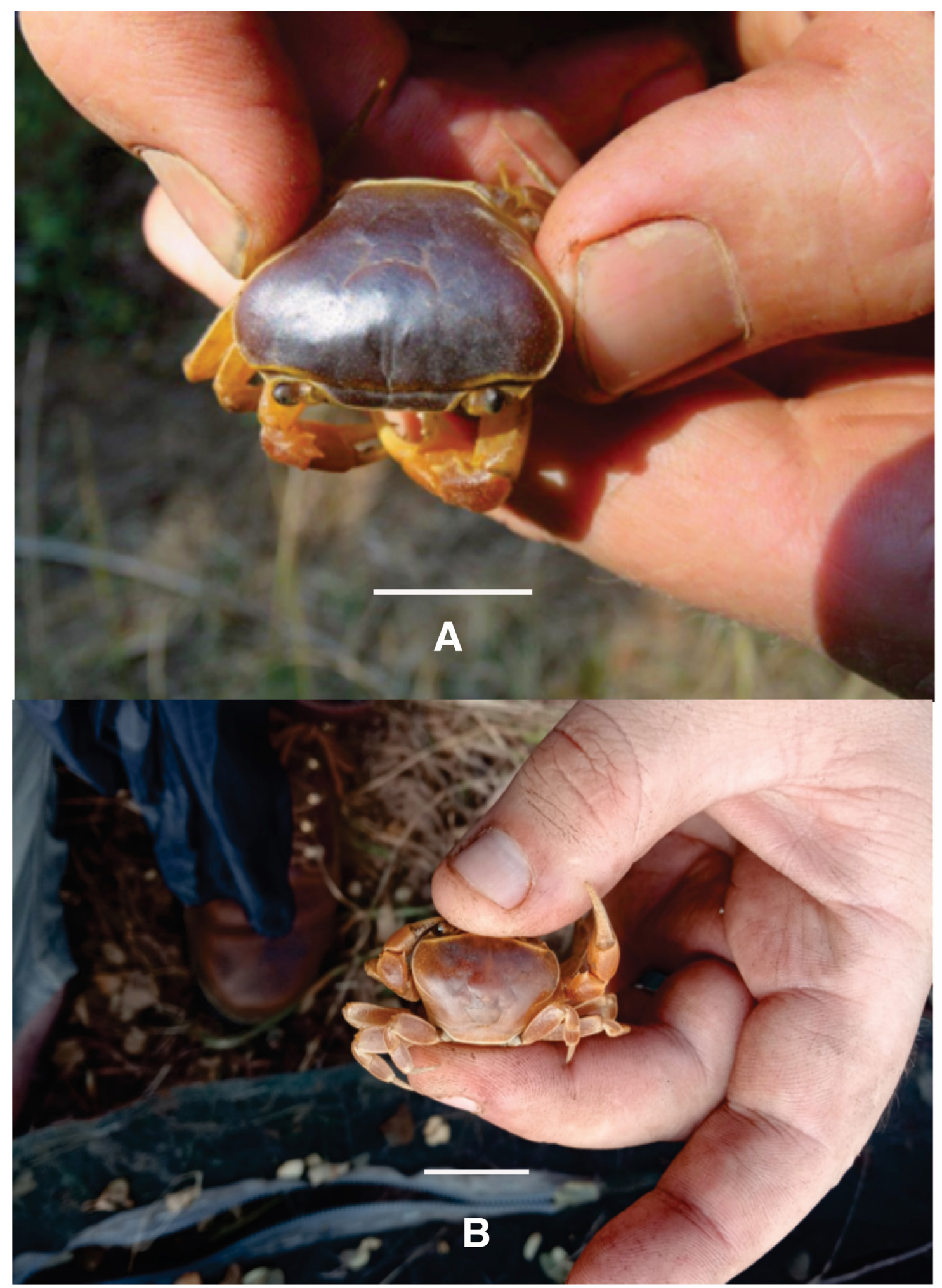

Fig. 5. A. Dorsal image of Potamonautes mariepskoppie sp. nov., when alive taken at the Blyde Canyon Nature Reserve, Mpumalanga Province, South Africa. B. Dorsal image of P. mariepskoppie sp. nov., of the specimen collected at Haenertsburg, Limpopo Province, South Africa. Scale bars $=10 \mathrm{~mm}$. 
to swamp forest patches east of Mariepskop and possibly at Haenertsburg, Limpopo province, while P. ntendekaensis is endemic to the Ntendeka Wilderness (Ngome forest - representing Eastern Scarp forest) area of KwaZulu-Natal, and P. ngoyensis is endemic to the Ngoye forest, part of the greater IOCB forest of KwaZulu-Natal (Daniels et al. 2019). Phylogenetically, Potamonautes mariepskoppie sp. nov. is not closely related to the five other species that occur in Mpumalanga province and can also easily be distinguished from these. Both $P$. unispinus and $P$. calcaratus have a single tooth on the anterolateral carapace margin, which is nearly spike-like in $P$. calcaratus. In $P$. unispinus the tooth on the anterolateral margin is sharp, pointed and prominent, similar to the exorbital tooth, and the species is large $(\mathrm{CL}=49.83 \mathrm{~mm})$ and broad $(\mathrm{CWW}=64.88 \mathrm{~mm})$. Potamonautes unispinus is a riverine species that is widespread in southern Africa and known from South Africa, Zimbabwe and Zambia (Stewart \& Cook 1998), while P. calcaratus occurs exclusively around ephemeral pans in the Kruger National Park in South Africa, where it burrows into the clay sidewalls up to $1 \mathrm{~m}$ (Daniels et al. 2002a). The latter species is also found in Mozambique and Zimbabwe (Reed \& Cumberlidge 2004). Additionally, the chelipeds of $P$. calcaratus are highly modified and nearly flattened for burrowing. The latter species has a vaulted carapace, indicative of its semi-terrestrial mode of life (Daniels pers. obs). In Potamonautes warreni, the dentition on the anterolateral margin of the carapace varies from a single tooth to a series of five to ten teeth (Daniels 2001). Potamonautes warreni is a riverine species widespread in South Africa, Botswana and Namibia where it occurs in the Orange River and its major tributaries such as the Vaal River. Potamonautes flavusjo, a Mpumalanga Highveld endemic, is semi-terrestrial and occurs in vlei (wetland) and lake areas, where it burrows into peat soils (Daniel et al. 2014). This species has characteristic sulphur-yellow patches on its dorsal carapace surface and the ventral surface is bright

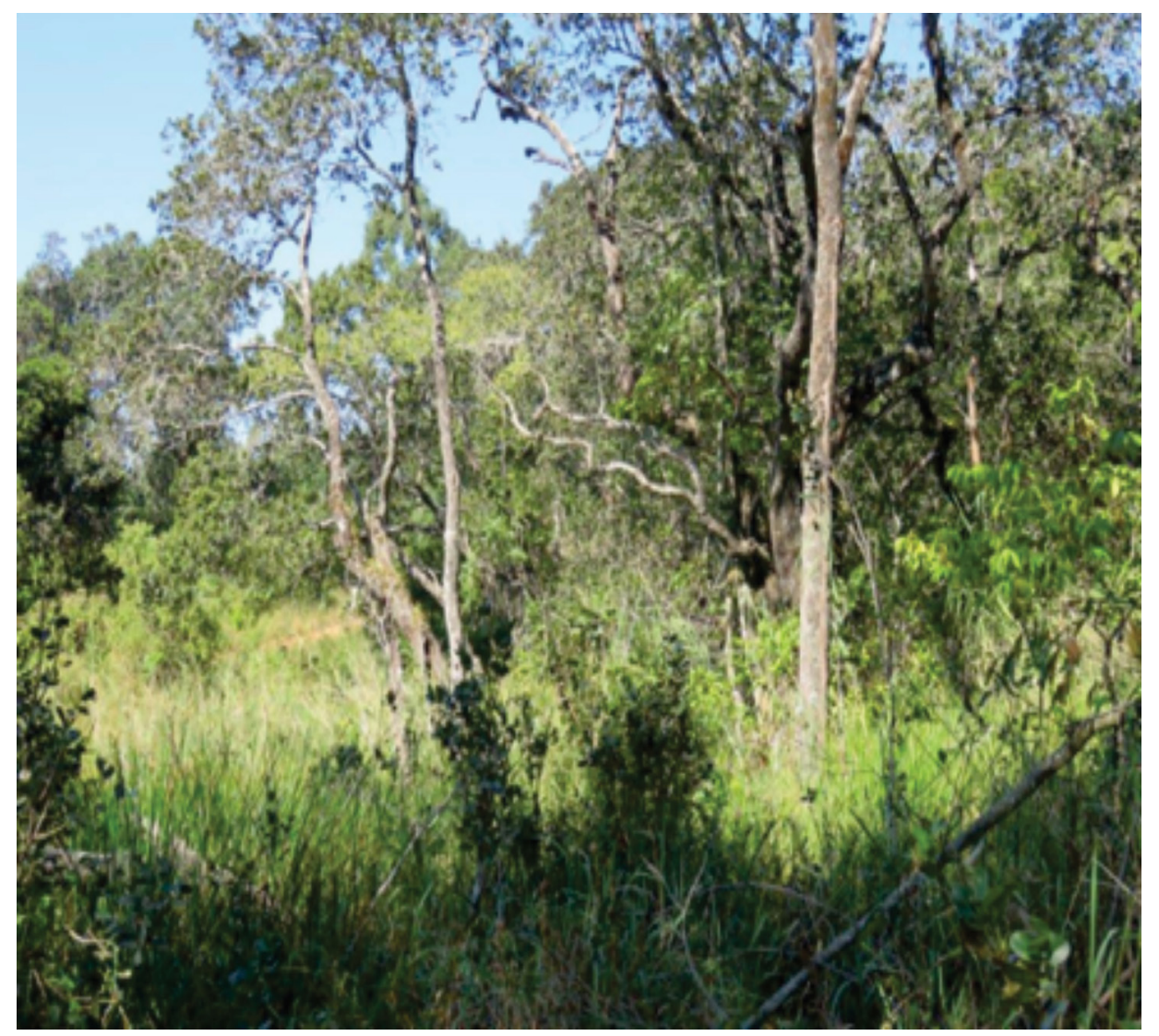

Fig. 6. Swamp forest habitat where P. mariepskoppie sp. nov., was collected at the Blyde Canyon Nature Reserve, below the Mariepskop Mountains, Mpumalanga Province, South Africa. 
yellow and the species has a highly vaulted carapace $(\mathrm{CH} / \mathrm{CL}=0.61)$ (Daniels et al. 2014). Potamonautes sidneyi sensu stricto is generally large-bodied $(\mathrm{CWW}>52.4 \mathrm{~mm})$ and the cephalothorax is flat $(\mathrm{CH} / \mathrm{CL}=$ 0.54 ), while the anterolateral margins of the carapace are heavily granulated. The species is common in large rivers, streams and swamp habitats throughout KwaZulu-Natal, Mpumalanga, Gauteng, Limpopo, the North-West and Northern Cape provinces of South Africa (Barnard 1950; Peer et al. 2017; Daniels unpubl).

The three remaining sister species to the clade containing P. mariepskoppie sp. nov. are all found in neighboring Southern African countries. Potamonautes gorongosa occurs at Gorongosa National Park in Mozambique, P. mutariensis occurs in the Zimbabwean Highlands and P. mulanjeensis occurs on Mount Mulanje in Malawi. Phylogenetically, P. mariepskoppie sp. nov. is distantly related to the two remaining swamp forest dwelling South African freshwater crab species, P. lividus and P. isimangaliso (Fig.1), although it does bear a superficial resemblance to these two species. Potamonautes lividus occurs in swamp forest patches in Eastern Cape province, at Dwesa Nature Reserve, Mazeppa Bay and Manubi State forest, and in the IOCB forests from Amatikulu Nature Reserve, Richards Bay, Empangeni, Tugela River Mouth, the University of Zululand campus, and Mapelane Nature Reserve in KwaZulu-Natal (Gouws et al. 2001; Daniels et al. 2020a). Potamonautes isimangaliso is confined to iSimangaliso Wetland Park in northern KwaZulu-Natal (Peer et al. 2015). Potamonautes lividus was originally described from Ficus and Barringtonia dominated forests, and the carapace of the species is blue or light blue (Gouws et al. 2001). Furthermore, the cephalothorax is ovoid with no epibranchial tooth and the carapace is highly vaulted $(\mathrm{CH} / \mathrm{CL}=0.64)$, indicative of a semi-terrestrial mode of life (Gouws et al. 2001). In P. isimangaliso, the cephalothorax is also ovoid, and the carapace is highly vaulted $(\mathrm{CH} / \mathrm{CL}=0.57)$ and light brown, maroon, purple or brown-black in colour (Peer et al. 2015). The species lives in ephemeral pans in sand forest where it burrows into the soil to a depth of $30-50 \mathrm{~cm}$ (Peer et al. 2015). Potamonautes mariepskoppie sp. nov., is distantly related to the undescribed species from Hogsback and the four mountain-living freshwater crab species from the Cape Fold Mountains (P. brincki, P. parvicorpus, P. parvispina and P. tuerkayi), and the three Great Drakensberg Escarpment species (P. clarus, $P$. depressus and $P$. baziya sp. nov).

\section{Taxonomic note}

H. Milne-Edwards (1853) described Thelphusa inflata from Durban, KwaZulu-Natal (formerly Port of Natal, Natal province). Barnard (1950) was of the opinion that Potamonautes inflatus is a variant of $P$. perlatus. In addition to Durban, Barnard (1950) also listed P. inflatus as being present at Belfast, Haenertsburg and Mariepskop in the former Transvaal province (notably, the last two localities are also where P. mariepskoppie sp. nov. occurs). Bott (1955) recognized $P$. inflatus as a junior subjective synonym of $P$. depressus, noting that the "type" is unknown or lost. Our phylogenetic results refute a close relationship between $P$. mariepskoppie sp. nov. and $P$. depressus. A search of the digital records of the Muséum national d'Histoire naturelle, Paris, France failed to identify the type specimen of $P$. inflatus, suggesting the holotype is lost. Similarly, an exhaustive search of the South African Museum of Natural History, Cape Town, failed to retrieve the material from Belfast, Mariepskop and Haenertsburg that Barnard (1950) assigned to P. inflatus. Researchers consider P. inflatus as an invalid taxon (Stewart et al. 1995; Gouws \& Stewart, 2001; Ng et al. 2008). A recent redescription of P. sidneyi suggests that the type material was likely originally collected from the region of Port Natal (Peer et al. 2017). The original description of $P$. inflatus is inadequate to differentiate it from $P$. sidneyi. Considering the absence of type material for $P$. inflatus and its confusing taxonomic status, the species name a nomen nudum. In recent years, six freshwater crab species, $P$. dentatus, $P$. lividus, $P$. isimangaliso, $P$. danielsi, $P$. ntendekaensis and $P$. ngoyensis, have been described from KwaZulu-Natal. Apart from P. sidneyi, no other species occurs in close geographic proximity to Durban (Port Natal) (Stewart et al. 1995; Peer et al. 2015, 2017; Daniels et al. 2019). The specimens from Mariepskop are recognized as P. mariepskoppie sp. nov., rather than $P$. inflatus, to limit any potential future confusion. 
Potamonautes baziya sp. nov.

urn:1sid:zoobank.org:act:32688368-D8DB-4B60-B801-99B43291E34A

Figs. 1,7-10; Table 1

\section{Diagnosis}

CARAPaCE. Ovoid, highly flat $(\mathrm{CH} / \mathrm{CL}=0.45)$ (Table 1$)$; postfrontal crest well-defined, complete, lateral ends meeting anterolateral margins; epigastric crests faint, median sulcus between crests short, not forked posteriorly; exorbital, epibranchial teeth reduced to granules; anterolateral carapace margin smooth (Fig. 7A).

ThIRD MAXILLIPED. Ischium with distinct vertical sulcus (Fig. 7B-C); s3/s4 complete, V-shaped, deep, midpoint almost meeting anterior margin of sterno-pleonal cavity; margins of s4 low, not raised (Fig. 7B).

CheLIPED. Dactylus (moveable finger) slim, highly arched, enclosing oval interspace, with three larger teeth interspersed by smaller teeth along length; propodus (fixed finger) with four larger teeth interspersed by smaller teeth along length (Fig. 8A ); carpus inner margin distal tooth large, pointed, proximal tooth reduced to granules (Fig. 8B); medial inferior margin of merus lined with series of small granules terminating distally at small, low distal meral tooth, lateral inferior margin smooth.

G1 TERMINAL ARTICLE. $1 / 3$ length of subterminal segment; first third straight in line with longitudinal axis of subterminal, middle part directed outward at $45^{\circ}$, widened by raised rounded ventral lobe, tip curving sharply upward (Fig. 9A-B).

\section{Etymology}

Named after the Baziya forest station. The specific epithet is used as a Latin noun in apposition.

\section{Material examined}

Holotype

SOUTH AFRICA - Eastern Cape Province - ${ }^{\lambda}$; Baziya Forest station, Afrotemperate forest streams; 313․917, S, $28^{\circ} 25.176^{\prime}$ E; 999 m a.s.1.; 19 May 2021; S.R. Daniels and A. Barnes; SAM A-094474.

Paratype

SOUTH AFRICA - Eastern Cape Province • 1 đ̊; same collection data as for holotype; SAM A-094475.

\section{Other material}

SOUTH AFRICA - Eastern Cape Province $\bullet 8 \propto+q, 8 \curvearrowright \curvearrowright, 4$ juvs; same collection data as for holotype ; SAM A-094476.

\section{Description}

Based on male holotype $(\mathrm{CWW}=40.30 \mathrm{~mm}$, Table 1$)$.

CARAPACE. Lacking dentition on the anteriolateral margins; widest anteriorly, narrowest posteriorly $(\mathrm{CWP} / \mathrm{CL}=0.47)$; flattened $(\mathrm{CH} / \mathrm{CL}=0.45)($ Fig. $7 \mathrm{~A})$; front broad, one-third of $\mathrm{CWW}(\mathrm{FW} / \mathrm{CWW}=$ 0.35); urogastric, cardiac grooves distinct, other grooves faint or missing; postfrontal crest complete, anterolateral margin posterior to epibranchial tooth smooth, meeting epibranchial teeth; epigastric crests faint, median sulcus between crests short, forked posteriorly; anterolateral margin between exorbital, epibranchial teeth faintly granulated, curving slightly outward, lacking intermediate tooth (Fig. 7B-C); branchiostegal wall vertical sulcus faint, meeting longitudinal sulcus, dividing branchiostegal wall into 
3 parts, suborbital, dorsal pterygostomial regions granulated, hepatic region smooth; suborbital margin faintly granulated.

THIRD MAXILLIPED. Filling entire buccal frame, except for respiratory openings; exopod with long flagellum, ischium with faint vertical groove (Fig. 9D). Epistomial tooth large, triangular, margins lined by large granules.

MANDiBLE. Palp two-segmented; terminal simple; tuft of setae at junction between segments.

Sternum. s1, s2 fused; s2/s3 deep, completely crossing sternum; s3/s4 complete, V-shaped, deep, midpoint almost meeting anterior margin of sterno-pleonal cavity; margins of s4 low, not raised.

CheliPed. Dactylus (moveable finger) slim, arched, enclosing oval interspace, with three larger teeth interspersed by smaller teeth along length; propodus (fixed finger) with four larger teeth interspersed by smaller teeth along length (Fig. 8A-B); carpus distal tooth large, pointed, proximal tooth small but distinct, followed by granule; both inferior margins of merus lined by series of small granules, distal meral tooth small, pointed.

PeREopods. Walking legs slender, pereopod 3 longest, 5 shortest; dorsal margins with fine sharp bristles, dactyli of walking legs ending in sharp point, with rows of spine-like bristles along segment.

Pleon. Outline broadly triangular with straight margins.

G1 TERMINAL ARTICLE. Short ( $1 / 3$ length of subterminal segment), curving away from midline, first third straight in line with longitudinal axis of subterminal, middle part directed outward at $45^{\circ}$, widened by low raised rounded ventral lobe, tip curving gently upward. G1 subterminal broad at base, tapering to slim junction with terminal article distally where these two parts have same width, ventral side of segment with heavily setose margins; with setae-fringed flap covering lateral half of segment; dorsal side smooth, no flap, with broad membrane on dorsal side of suture marking junction between terminal, subterminal parts (Fig. 9A-B).

G2. Terminal article long, flagellum-like, 0.5 times length of subterminal article (Fig. 9C).

\section{Size}

A medium-bodied species $(\mathrm{CL}=29.28 \mathrm{~mm}$ for holotype $)$ and wide $(\mathrm{CWW}=40.30 \mathrm{~mm})$.

\section{Colour in life}

Dark brown carapace when alive (Fig. 10A).

\section{Distribution}

To date, the species has only been collected from Baziya forest station. It is likely to also occur at other localities along the Great Drakensberg Escarpment in the Eastern Cape.

\section{Ecology}

The species occurs under large boulders in small mountain streams. The sides of the streams are covered by Afrotemperate forests at Baziya forest station outside of Mthatha, Eastern Cape province, South Africa (Fig. 10B). 

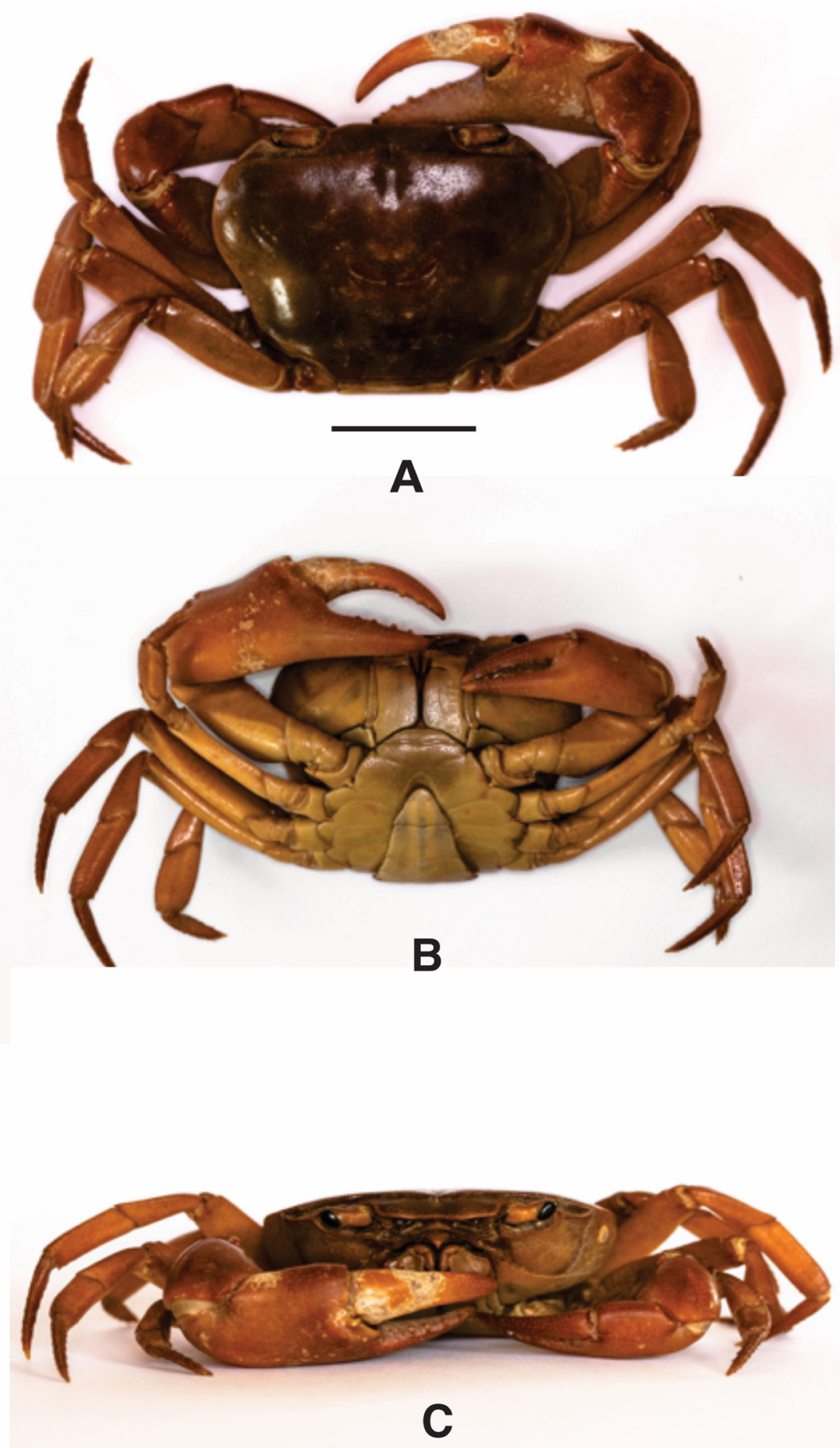

Fig. 7. Potamonautes baziya sp. nov., $\widehat{\partial}$, holotype $(\mathrm{CL}=29.28 \mathrm{~mm})$ (SAM A-094474). A. Entire animal, dorsal aspect. B. Entire animal, ventral aspect. C. Cephalothorax, frontal aspect. Scale bar $=10 \mathrm{~mm}$. 
Table 1. Potamonautes baziya sp. nov., measurements (in $\mathrm{mm}$ ) of the holotype and the range of additional male and female specimens examined.

\begin{tabular}{|c|c|c|c|c|}
\hline Variable & Abbreviation & Holotype & $\hat{0} \hat{0}$ & 우 우 \\
\hline carapace length & $\mathrm{CL}$ & 29.28 & $23.51-22.21$ & $27.53-24.04$ \\
\hline carapace width at widest point & CWW & 40.30 & $31.70-29.47$ & $37.30-33.30$ \\
\hline carapace posterior margin & CWP & 13.90 & $14.17-11.88$ & $15.22-12.56$ \\
\hline frontal width & FW & 14.41 & $12.63-11.35$ & $13.70-12.13$ \\
\hline $\begin{array}{l}\text { distance between postfrontal } \\
\text { crest and anterior margin }\end{array}$ & PFCD & 4.58 & $3.50-3.58$ & $3.63-3.46$ \\
\hline carapace height & $\mathrm{CH}$ & 13.46 & $11.28-9.79$ & $13.75-11.68$ \\
\hline major cheliped propodus length & MCPL & 34.83 & $24.32-18.88$ & $21.69-20.68$ \\
\hline major cheliped dactylus length & MCDL & 20.83 & $14.45-10.90$ & $12.30-11.79$ \\
\hline pereiopod 2 , merus length & P2ML & 16.57 & $12.39-11.61$ & $14.27-12.18$ \\
\hline pereiopod 2 , merus width & P2MW & 5.30 & $5.05-4.73$ & $5.48-5.04$ \\
\hline pereiopod 5 , merus length & P5ML & 16.42 & $14.21-12.50$ & $14.14-14.06$ \\
\hline pereiopod 5 , merus width & P5MW & 5.47 & $5.20-4.73$ & $5.47-5.25$ \\
\hline
\end{tabular}

\section{Remarks}

Potamonautes baziya sp. nov. is sister to P. depressus from the central Drakensberg Mountains, while P. clarus is sister to the latter clade (Fig. 1). The former pair of sister species can be differentiated based on colour when alive; P. baziya sp. nov. has a chocolate brown-coloured carapace, while P. depressus from the central Drakensberg Mountains has a dark brown to yellow brown carapace (Gouws et al. 2000). In addition, $P$. baziya sp. nov., has a narrower carapace dorsally $(\mathrm{CL} / \mathrm{CH}=2.17-2.08)$, while $P$. depressus has a more dorsally flattened carapace $(\mathrm{CL} / \mathrm{CH}=2.3-2.6)$ which is smooth (Peer et al. 2017). Potamonautes clarus is confined to the northern Drakensberg Mountains of KwaZulu-Natal (Gouws et al. 2000). Potamonautes clarus has a bright orange ovoid carapace when alive and viewed dorsally, while the species is cream coloured ventrally. The carapace is more vaulted $(\mathrm{CH} / \mathrm{CL}=0.49)$ and the species is small-bodied (CWW $=42.7 \mathrm{~mm}$ ) (Gouws et al. 2000). The dactylus of the right cheliped is highly arched in all three species, a pattern typical of mountain-dwelling species. The terminal segment of gonopod $1 \mathrm{in}$ P. clarus is slightly longer and more slender in comparison to P. depressus. Krauss (1843) only drew the dorsal aspect of $P$. depressus and did not illustrate gonopods one or two. From his original drawings, it is evident that the holotype has a highly arched right cheliped. The right cheliped of $P$. baziya sp. nov. is also arched, albeit less so than in the P. depressus holotype; this character is likely to vary with the age of the specimen. Bott (1955) illustrated the first gonopod of $P$. depressus, which differs from that of $P$. baziya sp. nov. in being slightly more tapered towards the tip. Cumberlidge \& Tavares (2006) reported that $P$. depressus is also possibly in Eastern Cape province. An examination of $P$. depressus specimens deposited in the South African Museum of Natural History, Cape Town, revealed two localities from the southern Drakensberg that are in Eastern Cape Province and, notably, also includes specimens from Hogsback. The latter locality represents the as yet undescribed species.

Four described mountain-living freshwater crab species occur in the Cape Fold Mountains. Potamonautes baziya sp. nov., can easily be distinguished from P. parvispina which has a yellowish, green-coloured carapace when alive, with an cephalothorax that is ovoid, a carapace that is flat $(\mathrm{CH} / \mathrm{CL}=0.50)$ and which is small-bodied $(\mathrm{CWW}=38.4 \mathrm{~mm}$ ). The species lives in first order streams in the Cederberg where is present in the upper reaches of the Olifants and Berg River systems in Western Cape Province (Stewart 1997b). Since P. parvispina has a small spine on the anterolateral carapace margins, it can easily be distinguished from the three other described species (Stewart 1997b). These three remaining species 


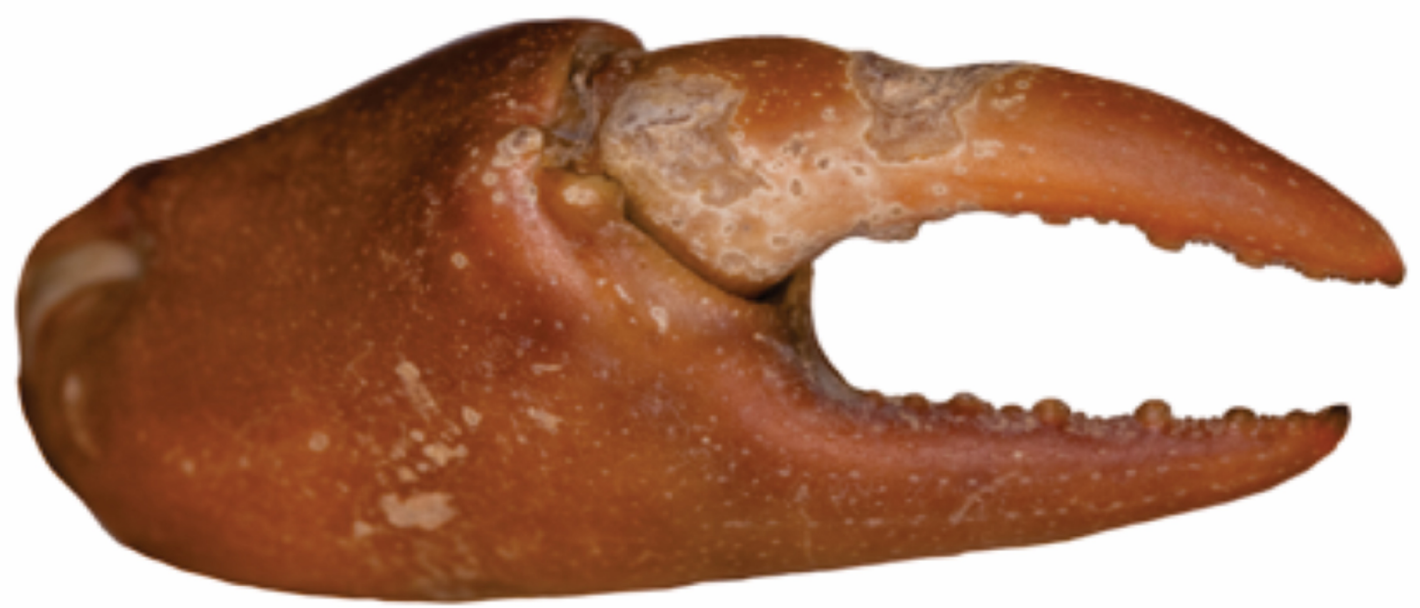

\section{A}

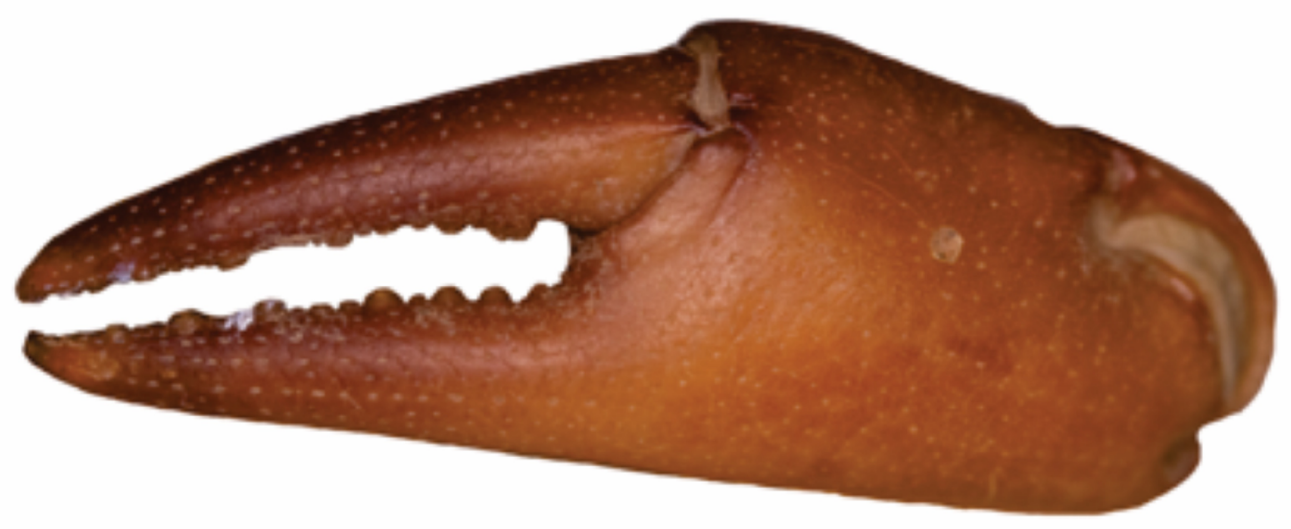

\section{B}

Fig. 8. Potamonautes baziya sp. nov., Ô, holotype, (SAM A-094474) A. Major right cheliped. B. Minor left cheliped. Scale bar $=10 \mathrm{~mm}$. 


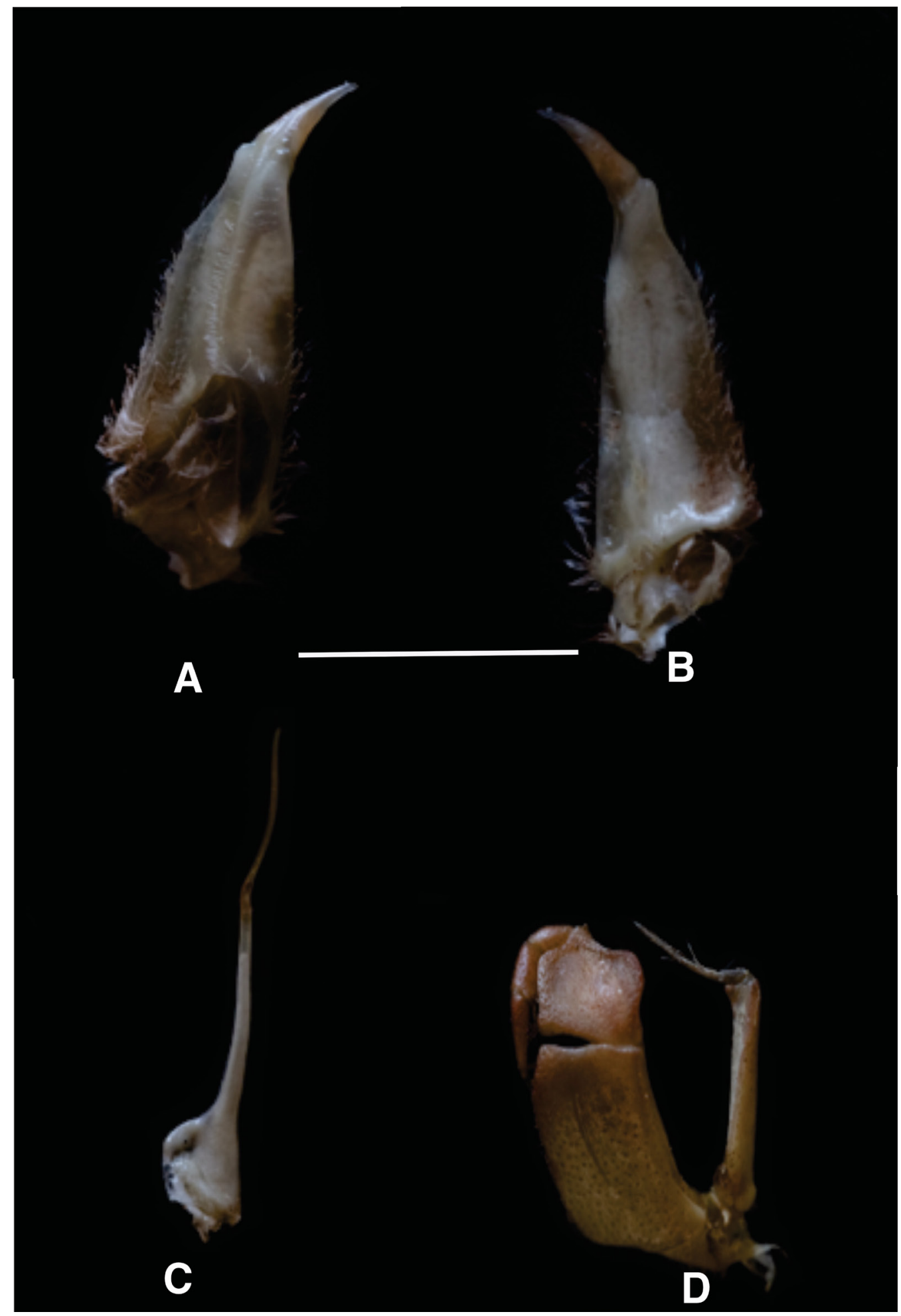

Fig. 9. Potamonautes baziya sp. nov., $\widehat{\partial}$, holotype (SAM A-094474) A. Left gonopod 1, anterior view. B. Left gonopod 1, posterior view. C. Left gonopod 2, anterior view. D. Right third maxilliped. Scale bar $=10 \mathrm{~mm}$. 


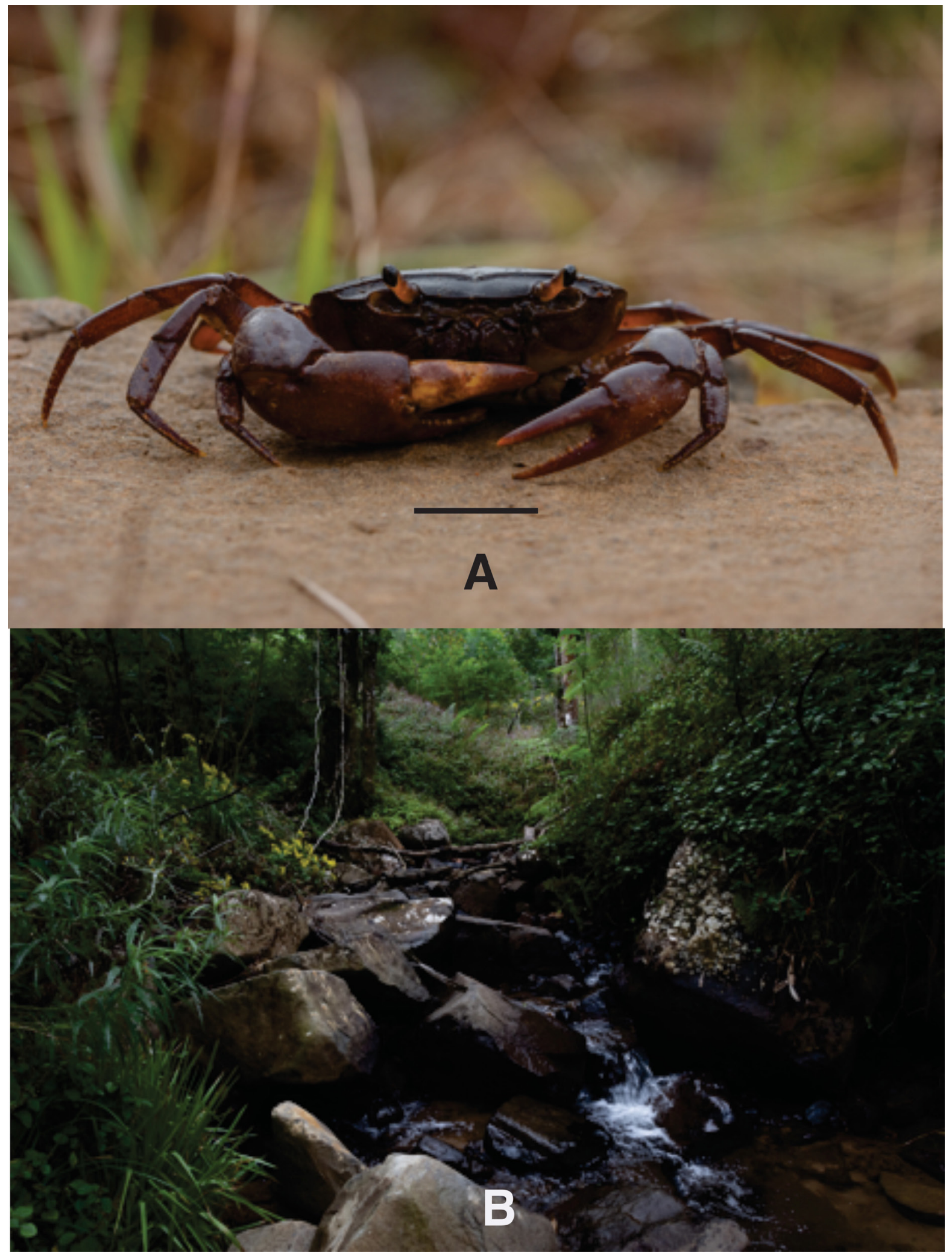

Fig. 10. A. Dorsal image of Potamonautes baziya sp. nov., when alive. Scale bar $=10 \mathrm{~mm}$. B. Afrotropical forest stream habitat where P. baziya sp. nov. was collected at Baziya forest station in Eastern Cape Province, South Africa. 
lack dentition on the anterolateral carapace margins, have an ovoid cephalothorax and are generally flat $(\mathrm{CH} / \mathrm{CL}<0.50)$, with P. parvicorpus being a small-bodied species $(\mathrm{CWW}=25.31 \mathrm{~mm})$ confined to the Cape Peninsula and the adjacent mountainous interior (Stewart 1997a; Daniels et al. 2001). Potamonautes brincki is also small-bodied $(\mathrm{CWW}=32.9 \mathrm{~mm})$ and known from the Hottentots Holland Mountains, while $P$. tuerkayi is also small-bodied $(\mathrm{CWW}=30 \mathrm{~mm})$ and known from the Overberg in Western Cape province, South Africa (Stewart 1997b; Daniels et al. 2001; Wood \& Daniels 2016). Ecologically, the three latter species occur under stones in first order, fast-flowing mountains streams, and occur sympatrically with $P$. perlatus in the lower reaches. The undescribed species from Hogback is also present at Katberg and Fort Fordyce Nature Reserve in the Eastern Cape, South Africa (Daniels unpubl.). The undescribed Hogsback species occurs along steep cliffs under stones in high altitude ( $>800 \mathrm{~m}$ a.s.1.) Afrotemperate forested areas where there is frequently very limited water flow, and it is sympatric with $P$. danielsi.

\section{Discussion}

Fine-scale sampling and the use of DNA sequence data has again helped in the discovery of two additional freshwater crab species from South Africa. Large areas of the interior of South Africa remain unsampled, particularly along mountains in Limpopo, Mpumalanga and the North West provinces of the country. Freshwater habitats in these areas should be targeted in future systematic surveys to collect crabs since they will likely harbor additional new species. In the countries neighbouring South Africa, such as Eswatini, Mozambique and Zimbabwe, limited sampling of freshwater habitats has occurred, suggesting that in these countries the diversity of freshwater crabs and other crustaceans is likely underestimated. For example, research in Mozambique has resulted in the description of four new freshwater crab species (P. bellarussus, P. gorongosa, P. namuliensis and P. licoensis) (Daniels \& Bayliss 2012; Daniels et al. 2014, 2020b; Cumberlidge et al. 2017) while two additional species from high altitude mountain streams still await formal description. All four of the aforementioned species were collected from inaccessible mountain areas that have not been sampled in decades. The application of DNA sequence data has now become an integral part of understanding phylogenetics as well as in aiding the description of novel lineages. Renewed efforts to document the aquatic biodiversity of southern Africa, focusing specifically on high altitude mountains areas, is required.

\section{Acknowledgments}

The University of Stellenbosch is thanked for logistical support to the first author, while the DNA sequencing unit at the Central Analytical Facility is thanked for sequencing. Jan Graf and Noxolo Mbebe are thanked for helping to collect the specimens at Mariepskop, Mpumalanga, South Africa. Dr Nasreen Peer is thanked for providing a specimen of the new species she is describing from Hogsback. Werner Conradie is thanked for sharing the images of $P$. mariepskoppie sp. nov., collected from Haenertsburg specimens in Limpopo province.

\section{References}

Akaike H. 1973. Information theory as an extension of maximum likelihood principle. In: Petrov B.N. \& Csake F. (eds) Second International Symposium on Information Theory: 267-281. Akademiai Kaido, Budapest.

Barnard K.H. 1950. Descriptive catalogue of South African decapod Crustacea (crabs and shrimps). Annals of the South African Museum 38: 1-837.

Bott R. 1955. Die Süßwasserkrabben von Afrika (Crust., Decap) und ihre Stammesgeschichte. Annales du Musée du Congo belge, C-Zoologie (3,3) 3: 209-352. 
Cumberlidge N. \& Tavares M. 2006. Remarks on the freshwater crabs of Angola, Southwest Africa, with the description of Potamonautes kensleyi, new species (Brachyura: Potamoidea: Potamonautidae). Journal of Crustacean Biology 26: 248-257. Available from https://academic.oup.com/jcb/article/26/2/248/2194884 [accessed 26 Nov. 2021].

Cumberlidge N., Naskrecki P. \& Daniels S.R. 2017. Potamonautes gorongosa, a new species of potamonautid freshwater crab from Mozambique, southern Africa. Nauplius 24: e2016029.

Available from https://www.scielo.br/j/nau/a/hhCMjPCrSKsmzNkR3ftbZNr/?lang=en [accessed 26 Nov. 2021].

Daniels S.R. 2001. Allometric growth, handedness and morphological variation in Potamonautes warreni (Calman, 1918) (Decapoda: Brachyura: Potamonautidae) with a redescription of the species. Crustaceana 74: 237-253. Available from https://brill.com/view/journals/cr/74/3/article-p237_2.xml [accessed 26 Nov. 2021].

Daniels S.R. 2017. Sympatric colour morphs or distinct species? Examining species boundaries amongst two South African freshwater crabs (Decapoda: Potamonautidae: Potamonautes MacLeay, 1838) with the description of a new species. Journal of Crustacean Biology 37: 723-731.

https://doi.org/10.1093/jcbiol/rux087

Daniels S.R. \& Bayliss J. 2012. Neglected refugia of biodiversity: mountainous regions in Mozambique and Malawi yield two novel freshwater crab species (Potamonautidae: Potamonautes). Zoological Journal of the Linnean Society 164: 498-509. https://doi.org/10.1111/j.1096-3642.2011.00773.x

Daniels S.R. \& Klaus S. 2018. Divergent evolutionary origins and biogeographic histories of two freshwater crabs (Brachyura: Potamonautes) on the West African conveyer belt islands of São Tomé and Príncipe. Molecular Phylogenetics and Evolution 127: 119-128.

https://doi.org/10.1016/j.ympev.2018.05.016

Daniels S.R., Stewart B.A. \& Burmeister L. 2001. Geographic patterns of genetic and morphological divergence amongst populations of a river crab (Decapoda: Potamonautidae) with the description of a new species from mountain streams in the Western Cape, South Africa. Zoologica Scripta 30: 181-197. https://doi.org/10.1046/j.1463-6409.2001.00061.x

Daniels S.R., Stewart B.A. \& Cook P.A. 2002a. Congruent patterns of genetic variation in a burrowing freshwater crab revealed by allozyme and mtDNA sequence analysis. Hydrobiologia 468: 171-179. https://doi.org/10.1023/A:1015203909091

Daniels S.R., Stewart B.A., Gouws G., Cunningham M. \& Matthee C.A. 2002b. Phylogenetic relationships of the southern African freshwater crab fauna (Decapoda: Potamonautidae: Potamonautes) derived from multiple data sets reveal biogeographic patterning. Molecular Phylogenetics and Evolution 25: $511-523$.

Daniels S.R., Cumberlidge N., Pérez-Losada M., Marijnissen S.A.E. \& Crandall K.A. 2006. Evolution of Afrotropical freshwater crab lineages obscured by morphological convergence. Molecular Phylogenetics and Evolution 40: 225-235. https://doi.org/10.1016/j.ympev.2006.02.022

Daniels S.R., Phiri E.E. \& Bayliss J. 2014. Renewed sampling of inland aquatic habitats in southern Africa yields two novel freshwater crab species (Decapoda: Potamonautidae: Potamonautes). Zoological Journal of the Linnean Society 171: 356-369. https://doi.org/10.1093/sysbio/syv011

Daniels S.R., Phiri E.E., Klaus S., Albrecht C. \& Cumberlidge N. 2015. Multilocus phylogeny of the Afrotropical freshwater crab fauna reveals historical drainage connectivity and transoceanic dispersal since the Eocene. Systematic Biology 64: 549-567. https://doi.org/10.1093/sysbio/syv011 
Daniels S.R., Busschau T. \& Cumberlidge N. 2019. Two new species of freshwater crabs of the genus Potamonautes MacLeay, 1838 (Decapoda: Brachyura: Potamonautidae) from the forests of KwaZuluNatal, South Africa. Journal of Crustacean Biology 39: 426-435. https://doi.org/10.1093/jcbiol/ruz024

Daniels S.R., James N. \& Gouws G. 2020a. Phylogeographic structure and continued surveys of a vulnerable South African freshwater crab (Potamonautidae, Potamonautes lividus): Implications for the IUCN Red Listing of the Afrotropical fauna. Aquatic Conservation of Marine and Freshwater Ecosystems 30: 2221-2239. https://doi.org/10.1002/aqc.3449

Daniels S.R., Bittencourt-Silva G.B., Muianga V. \& Bayliss J. 2020b. Phylogenetics of the freshwater crab (Potamonautes MacLeay, 1838) fauna from 'sky islands' in Mozambique with the description of a new species. European Journal of Taxonomy 716: 1-23. https://doi.org/10.5852/ejt.2020.716

Gouws G. \& Stewart B.A. 2001. Potamonautid river crabs (Decapoda: Brachyura: Potamonautidae) of KwaZulu-Natal, South Africa. Water SA 27: 85-98.

Gouws G., Stewart B.A. \& Coke M. 2000. Evidence for a new species of river crab (Decapoda: Brachyura: Potamonautidae) from the Drakensburg, South Africa. Journal of Crustacean Biology 20: 743-758. https://doi.org/10.1163/20021975-99990096

Gouws G., Stewart B.A. \& Reavell P.E. 2001. A new species of freshwater crab (Decapoda: Potamonautidae) from the swamp forests of KwaZulu-Natal, South Africa: biochemical and morphological evidence. Crustaceana 74: 137-160. https://doi.org/10.1163/156854001750096256

Gouws G., Peer N. \& Perissinatto R. 2015. mtDNA lineage diversity of a potamonautid freshwater crab in KwaZulu-Natal, South Africa. Koedoe 57: 1-12. https://doi.org/10.4102/koedoe.v57i1.1324

Krauss F. 1843. Südafrikanischen Crustaceen. Eine Zusammenstellung aller bekannten Malacostraca, Bemerkungen über deren Lebenswiese und geographische Verbreitung, nebst Beschreibung und Abbildung mehrer neuen Arten. E. Schweizerbart'sche Verlagsbuchhandlung, Stuttgart, Germany.

Ng P.K.L., Guinot D. \& Davie P. 2008. Systema Brachyurorum: Part 1. An annotated checklist of extant Brachyura crabs of the world. The Raffles Bulletin of Zoology 17: 1-296.

Ngwenya S.J., Torquebiau E. \& Furguson J.W.H. 2019. Mountains as a Critical Source of Ecosystem Services: the Case of the Drakensberg, South Africa. Centre of Environmental Studies University of Pretoria, Pretoria.

Peer N., Perissinotto R., Gouws G. \& Miranda N.A.F. 2015. Description of a new species of Potamonautes MacLeay, 1838, from the iSimangaliso Wetland Park, South Africa. ZooKeys 503: 23-43.

https://doi.org/10.3897/zookeys.503.9532

Peer N., Gouws G., Lazo-Wasem E., Perissinotto R. \& Miranda N.A.F. 2017. Redescription of Potamonautes sidneyi (Rathbun, 1904) (Decapoda, Potamonautidae) and description of a new species from KwaZulu-Natal, South Africa. ZooKeys 657: 1-28. https://doi.org/10.3897/zookeys.657.11623

Phiri E.E. \& Daniels S.R. 2014. Disentangling the divergence and cladogenesis in the freshwater crab species (Potamonautidae: Potamonautes perlatus) in the Cape Fold Mountains, South Africa, with the description of two novel cryptic lineages. Zoological Journal of the Linnaean Society 170: 310-332. https://doi.org/10.1111/zoj.12103

Phiri E.E. \& Daniels S.R. 2016. Multilocus coalescent species delimitation reveals widespread cryptic differentiation among Drakensberg mountain-living freshwater crabs (Decapoda: Potamonautes). Invertebrate Systematics 30: 60-74. https://doi.org/10.1071/IS15035

Posada D. 2008. jModelTest: phylogenetic model averaging. Molecular Biology and Evolution 25: 1253-1256. https://doi.org/10.1093/molbev/msn083 
Reed S.K. \& Cumberlidge N. 2004. Notes on the taxonomy of Potamonautes obesus (A Milne-Edwards, 1868) and Potamonautes calcaratus (Gordon, 1929) (Brachyura: Potamoidea: Potamonautidae) from eastern and southern Africa. Zootaxa 418 (1): -20. https://doi.org/10.11646/zootaxa.418.1.1

Ronquist F., Teslenko M., Van Der Mark P., Ayres D.L., Darling A., Höhna S., Larget B., Liu L., Suchard M.A. \& Huelsenbeck J.P. 2012. MrBayes 3.2: efficient Bayesian phylogenetic inference and model choice across a large model space. Systematic Biology 61: 539-542.

https://doi.org/10.1093/sysbio/sys029

Stewart B.A. 1997a. Morphological and genetic differentiation between populations of river crabs (Decapoda: Potamonautidae) from the Western Cape, South Africa with a taxonomic re-examination of Gecarcinautes brincki. Zoological Journal of the Linnean Society 119: 1-21.

https://doi.org/10.1111/j.1096-3642.1997.tb00133.x

Stewart B.A. 1997b. Biochemical and morphological evidence for a new species of river crab Potamonautes parvispina sp. nov. (Brachyura, Potamonautidae). Crustaceana 70: 737-753.

https://doi.org/10.1163/156854097X00168

Stewart B.A. \& Cook P.A. 1998. Identification of a new species of river crab (Decapoda: Brachyura: Potamonautidae) from South Africa using morphological and genetic data. Journal of Crustacean Biology 18: 48-61. https://doi.org/10.1163/193724098X00386

Stewart B.A., Coke M. \& Cook P.A. 1995. Potamonautes dentatus, new species, a freshwater crab (Brachyura: Potamoidea: Potamonautidae) from KwaZulu-Natal, South Africa. Journal of Crustacean Biology 15: 558-568. https://doi.org/10.1163/193724095X00541

Swofford D.L. 2002. PAUP* Phylogenetic Analysis Using Parsimony (and other methods), ver. 4.10. Illinois Natural History Survey, Champaign, Illinois.

Thompson J.D., Gibson T.J., Plewniak F., Jeanmougin F. \& Hiddins D.G. 1997. The CLUSTAL_X windows interface: flexible strategies for multiple sequence alignment aided by quality analysis tools. Nucleic Acids Research 25: 4876-4882. https://doi.org/10.1093/nar/25.24.4876

Trifinopoulos J., Nguyen L.T., von Haeseler A. \& Minh B.Q. 2016. W-IQ-TREE: a fast online phylogenetic tool for maximum likelihood analysis. Nucleic Acids Research 44: 232-235.

https://doi.org/10.1093/nar/gkw256

Van Rooyen L., Graf J., Mbebe N. \& Thifhulufhelwi R. 2020. Wetlands and Streams of the Upper Blyde, Sand and Klaserie Catchments. Status report, Award, Hoedspruit, South Africa.

Wood L.E. \& Daniels S.R. 2016. Genetic and morphological evidence for a new mountain-living freshwater crab species (Decapoda: Potamonautidae: Potamonautes) from the Western Cape province of South Africa. Invertebrate Systematics 30: 219-230. https://doi.org/10.1071/IS15051

Manuscript received: 29 July 2021

Manuscript accepted: 25 October 2021

Published on: 7 December 2021

Topic editor: Tony Robillard

Desk editor: Solène Kowalski

Printed versions of all papers are also deposited in the libraries of the institutes that are members of the EJT consortium: Muséum national d'histoire naturelle, Paris, France; Meise Botanic Garden, Belgium; Royal Museum for Central Africa, Tervuren, Belgium; Royal Belgian Institute of Natural 
Sciences, Brussels, Belgium; Natural History Museum of Denmark, Copenhagen, Denmark; Naturalis Biodiversity Center, Leiden, the Netherlands; Museo Nacional de Ciencias Naturales-CSIC, Madrid, Spain; Real Jardín Botánico de Madrid CSIC, Spain; Zoological Research Museum Alexander Koenig, Bonn, Germany; National Museum, Prague, Czech Republic. 